\title{
Attractiveness, non-preference for feeding and oviposition to Ascia monuste orseis Godart (Lepidoptera: Pieridae) in collard greens
}

\author{
Atratividade, não-preferência para alimentação e oviposição de \\ Ascia monuste orseis Godart (Lepidoptera: Pieridae) em couve comum
}

\author{
Luciano Nogueira' (1D, André Cirilo de Sousa Almeida², Marcelo Mueller de Freitas', \\ Zulene Antonio Ribeiro ${ }^{1}$, Arlindo Leal Boiça Junior ${ }^{1}$, Flávio Gonçalves de Jesus ${ }^{2 *}$
}

| | | | | | | | | | | | | | | | | | | | | | | | | | | | | | | | | | | | | | | | | | | | | | | | | | | | | | | | | | | | | | | | | | | | | | | | | | | | | | | | | | | | | | | | | | | | | | | | | | | | | | | | | | | | | | | | | | | | | | | | | | | | | | | | | | | | | | | | | | | | | | | | | | | | | | | | | | | | | | | | | | | | | | | | | | | | | | | | | | | | | | | | | | | | | | | | | | | || ||

\begin{abstract}
Collard greens Brassica oleracea var. acephala is one of the most important horticultural grown in Brazil for human feeding. The caterpillar Ascia monuste orseis (Lepidoptera: Pieridae) stands out among the important pest in Brassicaceae causing severe plant defoliation. The objective of this study was to identify resistant genotypes (antixenosis) in 26 collard greens genotypes to $A$. monuste orseis. In free-choice test, randomized blocks were used; and in the non-choice test we adopted a completely randomized design. Manteiga de Jundiaí, crespa de Capão Bonito, couve de Arthur Nogueira 1, manteiga I-1811, manteiga de Ribeirão Pires I-1811, orelha-de-elefante and Pires 1 de Campinas presented antixenosis (non-preference for oviposition). Pires 1 de Campinas, manteiga I-1811, manteiga de São José, verde-escura and manteiga de Monte Alegre presented antixenosis (non-preference for feeding). These collard greens genotypes can be directly used by farmers for cultivation or by breeders as donor sources in breeding programs for resistance to A. monuste orseis.
\end{abstract}

KEYWORDS: Great southern white; plant resistance to insect; Brassicaceae; integrated pest management.
RESUMO: Brassica oleracea var. acephala (couve comum) é uma das mais importantes olerícolas cultivadas no Brasil para alimentação humana. A lagarta Ascia monuste orseis (Lepidoptera: Pieridae) destaca-se entre as pragas mais significativas no cultivo de Brassicaceae por causar severa desfolha na planta. O objetivo deste trabalho foi identificar, em 26 genótipos de couve comum, fontes de resistência (antixenose) a A. monuste orseis. No teste de livre escolha, adotou-se o esquema casualizado de blocos; e no teste sem chance de escolha o esquema foi inteiramente casualizado. Manteiga de Jundiaí, crespa de Capão Bonito, couve de Arthur Nogueira 1, manteiga I-1811, manteiga de Ribeirão Pires I-1811, orelha-de-elefante e Pires 1 de Campinas apresentaram antixenose (não preferência para oviposição). Pires 1 de Campinas, manteiga I-1811, manteiga de São José, verde-escura e manteiga de Monte Alegre apresentaram antixenose (não preferência para alimentação). Esses genótipos de couve comum podem ser cultivados diretamente por agricultores ou ser usados por melhoristas em programas de melhoramento genético para resistência a $A$. monuste orseis.

PALAVRAS-CHAVE: curuquerê-da-couve; resistência de plantas a inseto; Brassicaceae; controle integrado de pragas. 


\section{INTRODUCTION}

The collard greens Brassica oleracea var. acephala is one of the most important horticultural species grown in Brazil for feeding and are cultivated in small home gardens (FILGUEIRA, 2008). In Brazil, the caterpillar Ascia monuste orseis (Lepidoptera: Pieridae) stands out among the important pests in Brassicaceae causing severe plant defoliation (SCHLICK-SOUZA et al., 2011; BALDIN et al., 2015).

The presence of the pest is observed in Brassicaceae such as watercress (Lepidium ruderale), broccoli (Brassica oleracea var. italica), mustard (Sinapis arvensis), turnip (Raphanus sativus), cabbage (Brassica oleracea var. capitata), cauliflower (Brassica oleracea var. botrytis), Chinese cabbage (Brassica rapa var. pekinensis) (CHAMBERLIN; KOK, 1986; LASOTA; KOK, 1989; KOK; ACOSTA-MARTINEZ, 2001) and Crataeva tapia, one species with silvicultural importance (PRATISSOLI et al., 2007).

The control of $A$. monuste orseis is performed by periodically application of chemical insecticides (GALLO et al., 2002). These products may cause several problems, such as residues in food, elimination of natural enemies and selection of resistant insects (ROEL et al., 2000).

The use of resistant varieties of collard greens may represent an important strategy for $A$. monuste orseis control. In some case, the host plant resistance has proved to be effective with other pest control methods and compatible in integrated pest management (IPM) systems, reducing the pest population density to below economic injury levels (LARA, 1991; EIGENBRODE; TRUMBLE, 1994; SEIFI et al., 2013).

Resistance in Brassicaceae can be manifested by antibiosis, that can cause detrimental effects to insect herbivores such as failure to grow, higher rates of mortality, and prolongation of the life cycle (LARA, 1991; SMITH, 2005); and by antixenosis, that affects the insect behavior in the choice for feeding and oviposition (PANDA, 1979; SMITH, 2005; NOGUEIRA et al., 2015).

In Brazil, few studies have been reported for resistance of collard greens to A. monuste orseis. These results are based mainly on pest biological parameters, and rarely the plant characteristics are observed (SCHLICK-SOUZA et al., 2011). Antixenosis (non-preference for oviposition) was noticed by A. monuste orseis on manteiga de Jundiaí, comum, Arthur Nogueira Z, manteiga de Ribeirão Pires I-2446, manteiga de Ribeirão Pires I-2620 and tronchuda portuguesa. The nonpreference for feeding by $A$. monuste orseis was verified on japonesa, Pires 1 de Campinas, roxa I-919 e manteiga de São Roque I-812 (SCHLICK-SOUZA et al., 2011). These causes of resistance are manifested in Brassicaceae due to chemical (BERNAYS; CHAPMAN, 1994; THULER et al., 2007; SHARON et al., 2009; BALDIN; BENEDUZZI, 2010), morphological (FARNHAM; ELSEY, 1995), or physical characteristics (VENDRAMIM; GUZZO, 2009; SCHLICKSOUZA et al., 2011).
The objective of this study was to identify resistant genotypes (antixenosis) in 26 collard greens genotypes to A. monuste orseis.

\section{MATERIAL AND METHODS}

The seedlings of genotypes were obtained from the Insects Plant Resistance Laboratory at the Faculty of Agricultural and Veterinary Sciences of São Paulo State University "Júlio de Mesquita Filho" (UNESP), in Jaboticabal, Sáo Paulo, Brazil, which were transplanted into field conditions at Goiano Federal Institute, in Campus Urutaí, Goiás, Brazil. The genotypes manteiga de Mococa, manteiga de Jundiaí, manteiga de Tupi, Pires 2 de Campinas, Vale das Garças, crespa de Capão Bonito, couve Arthur Nogueira 1, couve Arthur Nogueira 2, Hortolândia, orelha-de-elefante, crespa I-918, manteiga I-1811, manteiga de Ribeirão Pires I-2620, verde-escura, Pires 1 de Campinas, verde-claro, manteiga de São José, manteiga de Monte Alegre, roxa I-919, comum, manteiga de Sáo Roque I-1812, manteiga de Jaboticabal, Geórgia 1, Geórgia 2 and gigante I-915 were adopted.

\section{Ascia monuste orseis rearing}

Eggs were collected in collard greens field and placed in Petri dishes (14 cm diameter) at the laboratory conditions (temperature $25 \pm 2^{\circ} \mathrm{C}$, relative humidity $70 \pm 10 \%$ and photoperiod 12:12 light/darkness) on filter paper moistened until the caterpillars hatching.

The newly hatched larvae were moved to rearing cages ( $50 \times 30 \mathrm{~cm}$ in diameter), lined with filo screen attached by elastic band on the top. The base of the cage was lined with paper towels to absorb excrement moisture. Initially 50 first instar caterpillars were set up per cage; they were used for conducting experiments and other held to adult stage for the test of non-preference for oviposition. The caterpillar rearing was fed with fresh leaves of the manteiga cultivar. These leaves were remained embedded in pots $(250 \mathrm{~mL})$ containing water and were renewed daily.

The pupae were placed in emergency cages (plastic cups $300 \mathrm{~mL}$ ) with the base lined with paper towel and closed at the top with filo screen attached by elastic band on top. After emergence, adults that were not used in the experiments were released in field to ensure copulation and oviposition for egg collecting.

\section{Attractiveness and non-preference for oviposition}

The attractiveness in free-choice test was evaluated, offering leaf discs of genotypes for third-instar larvae. The leaves 
were collected in the apical plants position at 40 days after transplantation (DAT). The leaf disc was cutted $(2.5 \mathrm{~cm}$ diameter) and distributed in circular arenas $(35 \mathrm{~cm}$ diameter and $6 \mathrm{~cm}$ height) on moistened filter paper. From the leaves collected in each genotype, two equidistant leaf discs were taken, one offered to insects, and other "aliquot" was placed in an oven at $60^{\circ} \mathrm{C}$, for 48 hours. Then, by the difference between the consumed remaining leaf disc and the aliquot, it was determined the dry matter consumed by the larvae. The attractiveness in non-choice test was evaluated in Petri dish ( $6 \mathrm{~cm}$ diameter), by offering the same genotypes individually, and the collected leaves were processed in the same way as the previous experiment. The dry matter consumed was determined using the same methodology described previously.

In both attractiveness tests, the number of larvae in the leaf discs of each genotype was counted at 1, 3, 5, 10, 15, 30 minutes and 1, 2, 6 and 24 hours after larvae release. A randomized block design was carried out for attractiveness in free-choice (10 replications). For attractiveness in nonchoice test, a completely randomized design was performed (30 replications).

At the end of the attractiveness tests, the attractiveness index was calculated using the formula expressed by Equation 1:

$\mathrm{AI}=2 \mathrm{C} /(\mathrm{C}+S)$

In which:

$\mathrm{IA}=$ attractiveness index;

$\mathrm{C}=$ number of insects attracted to the evaluated genotype;

$S=$ number of insects attracted to the susceptible pattern (Geórgia I).

AI values range between 0 and 2 , considering that 1 indicates attraction similar among the evaluated genotype and susceptible standard, IA $<1$ corresponds to a smaller attraction, and IA $>1$ indicates greater attraction in the evaluated genotype against the susceptible standard. Geórgia I was adopted as a susceptible pattern, because it is widely grown commercially by fammers, and was also used as a susceptible pattern to Plutella xylostella (Lepidoptera: Plutellidae) (THULER et al., 2007).

The non-preference for oviposition was evaluated in freechoice tests in cages ( $2.5 \mathrm{~m}$ long $\times 3.0 \mathrm{~m}$ wide $\times 2.8 \mathrm{~m}$ height), which were placed in equidistant form. Container containing plants from all genotypes with 40 DAT were used and placed in the center of the cage with a couple of $A$. monuste orseis per genotype. The parameters evaluated were: attractiveness in free and non-choice test, egg mass and egg numbers at 72 hours after adult release. A randomized block design (five replications) was adopted.

The oviposition preference index was calculated by the formula expressed on Equation 2:
$\mathrm{OPI}=[(\mathrm{C}-\mathrm{S}) /(\mathrm{C}+\mathrm{S})] \times 100$

In which:

OPI = oviposition preference index;

$\mathrm{C}=$ number of eggs counted in the genotype evaluated;

$S=$ number of eggs counted in the susceptible pattern (Geórgia I).

The index ranged from +100 (very stimulating) to -100 (complete deterrence), considering 0 indicates neutrality (FENEMORE, 1980).

\section{Statistical analysis}

The residual normality and homoscedasticity were checked by applying Shapiro-Wilk and Bartlett tests. When the aphid number data did not meet these assumptions, the Box-Cox method was used in order to find an optimal transformation. The transformed data were used to fit analysis of variance models and the means compared using Scott-Knott's test $(\alpha=0.05)$. The means were back-transformed for presentation purposes. All analyses were performed using $R$ software, version 3.2.2.

\section{RESULTS}

The genotypes were statistically different $(\mathrm{F}=1.91 ; \mathrm{df}=25$; $\mathrm{p}=0.0056)$ in free-choice test, and the genotypes 15 and 19 were the most attractive (Table 1). The attractiveness index to $A$. monuste orseis showed differences between the susceptible pattern (Geórgia I). The genotypes 3, 5, 6, 9, 15, 21, 22 e 23 were stimulant neutral and the other ones classified as deterrents (Fig. 1).

The genotypes were statistically different $(\mathrm{F}=2.58$; $\mathrm{df}=25 ; \mathrm{p}=0.0059)$ in non-choice test (Table 2), and the genotype 1 differed from the others as the most attractive. The attractiveness index in non-choice test, the genotypes 15,2 and 19 were classified as stimulants. The genotypes 10 , 11,12 and 16 were classified as neutral, and remaining genotypes were classified as deterrents, except the susceptible patter (Geórgia I) (Fig. 2).

The dry matter consumed by $A$. monuste orseis in freechoice $(\mathrm{F}=5.12 ; \mathrm{df}=25 ; \mathrm{p}<0.0005)$ and non-choice tests $(\mathrm{F}=33.13 ; \mathrm{df}=25 ; \mathrm{p}<0.0005)$ were significantly different (Table 3$)$. The consumption in free-choice test was higher in 2 , $11,24,13,9,16,19,14,3,10,1,5,7$ and 8 , differing from $6,21,17,22,20,25,4,26$ and 15, with the lowest values. In non-choice test, the genotype 7 was the most consumed by $A$. monuste orseis, differing from 18,12, 15 and 19, with the lowest consumption.

The feeding preference index in free and non-choice tests showed differences between the susceptible pattern (Geórgia I). 
Table 1. Mean number ( $\pm \mathrm{SE}$ ) of third-instar larvae in free-choice test of Ascia monuste orseis in collard greens genotypes (temperature $25 \pm 2{ }^{\circ} \mathrm{C}$, relative humidity $70 \pm 10 \%$ and photoperiod $12: 12$ light/darkness).

\begin{tabular}{|c|c|c|c|c|c|c|}
\hline Genotypes & Code & $1 \mathrm{~h}$ & $2 \mathrm{~h}$ & $6 \mathrm{~h}$ & $12 \mathrm{~h}$ & Total \\
\hline Manteiga de Mococa & 1 & $1.9 \pm 1.3 a$ & $1.4 \pm 0.86 b$ & $0.9 \pm 0.71$ & $1.0 \pm 0.56 b$ & $5.2 \pm 0.23 b$ \\
\hline Manteiga de Jundiaí & 2 & $1.8 \pm 1.1 \mathrm{a}$ & $2.4 \pm 1.34 \mathrm{a}$ & $1.8 \pm 1.24$ & $1.8 \pm 0.83 b$ & $7.8 \pm 0.15 b$ \\
\hline Manteiga de Tupi & 3 & $1.9 \pm 1.0 \mathrm{a}$ & $1.4 \pm 0.95 b$ & $0.5 \pm 0.17$ & $1.5 \pm 0.83 b$ & $5.3 \pm 0.30 b$ \\
\hline Pires 2 de Campinas & 4 & $0.8 \pm 0.5 b$ & $0.5 \pm 0.31 b$ & $0.2 \pm 0.20$ & $1.0 \pm 0.39 b$ & $2.5 \pm 0.18 b$ \\
\hline Vale das Garças & 5 & $0.3 \pm 0.2 b$ & $0.3 \pm 0.21 b$ & $1.8 \pm 1.48$ & $0.2 \pm 0.13 b$ & $2.6 \pm 0.38 b$ \\
\hline Crespa de Capão Bonito & 6 & $0.9 \pm 0.6 b$ & $0.3 \pm 0.21 b$ & $0.9 \pm 0.53$ & $0.7 \pm 0.34 b$ & $2.8 \pm 0.14 b$ \\
\hline Couve Arthur Nogueira 1 & 7 & $0.2 \pm 0.2 b$ & $0.0 \pm 0.00 \mathrm{~b}$ & $0.0 \pm 0.00$ & $0.5 \pm 0.31 b$ & $0.7 \pm 0.12 b$ \\
\hline Couve Arthur Nogueira 2 & 8 & $0.8 \pm 0.3 b$ & $0.4 \pm 0.22 b$ & $0.3 \pm 0.15$ & $1.0 \pm 0.52 b$ & $2.5 \pm 0.17 b$ \\
\hline Hortolândia & 9 & $0.5 \pm 0.3 b$ & $0.7 \pm 0.26 b$ & $1.3 \pm 0.99$ & $1.3 \pm 0.50 b$ & $3.8 \pm 0.21 b$ \\
\hline Orelha-de-elefante & 10 & $2.2 \pm 1.0 \mathrm{a}$ & $1.6 \pm 0.64 b$ & $1.1 \pm 0.48$ & $2.2 \pm 0.68 b$ & $7.1 \pm 0.27 b$ \\
\hline Crespa I-918 & 11 & $1.9 \pm 1.3 \mathrm{a}$ & $1.2 \pm 0.55 b$ & $1.3 \pm 0.91$ & $1.9 \pm 066 b$ & $6.3 \pm 0.19 b$ \\
\hline Manteiga I-1811 & 12 & $2.1 \pm 0.7 \mathrm{a}$ & $1.6 \pm 0.67 b$ & $1.5 \pm 0.67$ & $2.1 \pm 0.62 b$ & $7.3 \pm 0.16 b$ \\
\hline Manteiga de Ribeirão Pires I-1811 & 13 & $0.6 \pm 0.3 b$ & $0.7 \pm 0.40 \mathrm{~b}$ & $0.3 \pm 0.21$ & $0.8 \pm 0.33 b$ & $2.4 \pm 0.11 b$ \\
\hline Manteiga de Ribeirão Pires I-2620 & 14 & $0.2 \pm 0.2 b$ & $0.3 \pm 0.15 b$ & $0.4 \pm 0.31$ & $1.1 \pm 0.38 b$ & $2.0 \pm 0.20 \mathrm{~b}$ \\
\hline Verde-escura & 15 & $3.4 \pm 0.7 a$ & $4.5 \pm 1.39 a$ & $2.8 \pm 1.20$ & $3.4 \pm 1.06 a$ & $14.1 \pm 0.35 a$ \\
\hline Pires 1 de Campinas & 16 & $2.1 \pm 0.7 a$ & $1.2 \pm 0.51 b$ & $1.3 \pm 0.62$ & $1.6 \pm 0.56 b$ & $6.2 \pm 0.20 b$ \\
\hline Verde-clara & 17 & $0.1 \pm 0.1 \mathrm{~b}$ & $0.3 \pm 0.21 b$ & $0.2 \pm 0.20$ & $0.7 \pm 0.30 \mathrm{~b}$ & $1.3 \pm 0.13 b$ \\
\hline Manteiga de São José & 18 & $1.2 \pm 0.9 b$ & $1.3 \pm 0.99 b \mathrm{a} \mathrm{b}$ & $0.4 \pm 0.31$ & $1.8 \pm 0.96 b$ & $4.7 \pm 0.29 b$ \\
\hline Manteiga de Monte Alegre & 19 & $0.9 \pm 0.4 b$ & $2.4 \pm 0.87 \mathrm{a} a b$ & $2.3 \pm 1.24$ & $2.5 \pm 0.86 a$ & $8.1 \pm 0.38 a$ \\
\hline Roxa I-919 & 20 & $0.8 \pm 0.8 b$ & $0.0 \pm 0.00 \mathrm{~b}$ & $0.7 \pm 0.52$ & $0.5 \pm 0.40 b$ & $2.0 \pm 0.18 b$ \\
\hline Couve comum & 21 & $0.4 \pm 0.2 b$ & $0.6 \pm 0.50 \mathrm{~b}$ & $2.5 \pm 1.19$ & $0.5 \pm 0.31 b$ & $4.0 \pm 0.50 \mathrm{~b}$ \\
\hline Manteiga de São Roque I-1812 & 22 & $0.6 \pm 0.4 b$ & $1.0 \pm 0.70 b$ & $0.7 \pm 0.50$ & $1.0 \pm 0.52 b$ & $3.3 \pm 0.10 b$ \\
\hline Manteiga de Jaboticabal & 23 & $0.5 \pm 0.2 b$ & $0.2 \pm 0.13 b$ & $0.9 \pm 0.53$ & $0.6 \pm 0.31 b$ & $2.2 \pm 0.14 b$ \\
\hline Geórgia 1 & 24 & $2.0 \pm 0.9 a$ & $1.6 \pm 0.62 b$ & $1.5 \pm 0.60$ & $1.6 \pm 0.62 b$ & $6.7 \pm 0.11 b$ \\
\hline Geórgia 2 & 25 & $1.6 \pm 0.9 b$ & $0.6 \pm 0.40 \mathrm{~b}$ & $0.7 \pm 0.37$ & $1.0 \pm 0.47 b$ & $3.9 \pm 0.23 b$ \\
\hline Gigante I-915 & 26 & $1.3 \pm 0.8 b$ & $0.9 \pm 0.71 b$ & $1.2 \pm 0.81$ & $0.6 \pm 0.70 \mathrm{~b}$ & $4.0 \pm 0.16 b$ \\
\hline F (Treat) & - & $1.30^{*}$ & $2.25^{* *}$ & $1.02^{\text {ns }}$ & $1.53^{* *}$ & $1.91^{* *}$ \\
\hline C. V. (\%) & - & 57.36 & 56.24 & 60.73 & 50.77 & 56.81 \\
\hline
\end{tabular}

'Means followed by the same letter are not statistically different from each other, by Scott-Knott test at 5\% probability; SE: average standard error; *significant at $5 \%$ probability; ${ }^{* *}$ significant at $1 \%$ probability; ${ }^{\text {Ns}}$ : not significant; C. V.: coefficient of variation.

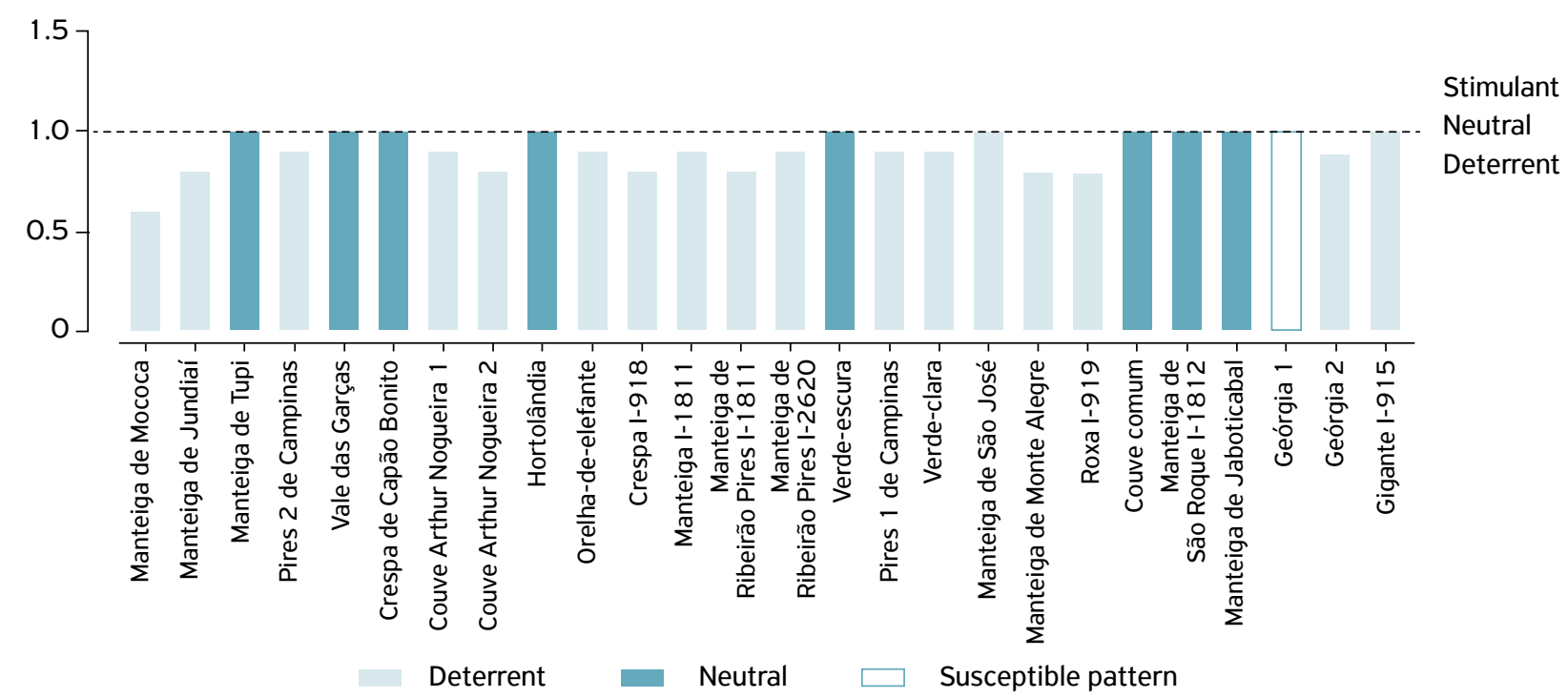

Figure 1. Attractiveness index of Ascia monuste orseis (Lepidoptera: Pieridae) in collard greens genotypes in free-choice test (temperature $25 \pm 2^{\circ} \mathrm{C}$, relative humidity $70 \pm 10 \%$ and photoperiod $12: 12$ light/darkness). 
Table 2. Mean number ( $\pm \mathrm{SE}$ ) of third-instar larvae in non-choice test of Ascia monuste orseis in collard greens genotypes (temperature $25 \pm 2{ }^{\circ} \mathrm{C}$, relative humidity $70 \pm 10 \%$ and photoperiod $12: 12$ light/darkness).

\begin{tabular}{|c|c|c|c|c|c|}
\hline Genotypes & $1 \mathrm{~h}$ & $2 \mathrm{~h}$ & $6 \mathrm{~h}$ & $12 \mathrm{~h}$ & Total \\
\hline 1 & $0.2 \pm 0.13 b$ & $0.2 \pm 0.13 c$ & $0.2 \pm 0.13 b$ & $0.8 \pm 0.13 a$ & $0.35 \pm 0.15 b$ \\
\hline 2 & $0.2 \pm 0.13 b$ & $0.3 \pm 0.15 c$ & $0.9 \pm 0.10 \mathrm{a}$ & $0.8 \pm 0.13 a$ & $0.55 \pm 0.18 a$ \\
\hline 3 & $0.7 \pm 0.15 a$ & $0.8 \pm 0.13 a$ & $1.0 \pm 0.00 \mathrm{a}$ & $0.8 \pm 0.13 a$ & $0.83 \pm 0.06 a$ \\
\hline 4 & $0.8 \pm 0.13 a$ & $0.7 \pm 0.15 a$ & $0.9 \pm 0.10 a$ & $0.8 \pm 0.13 a$ & $0.80 \pm 0.04 a$ \\
\hline 5 & $0.8 \pm 0.13 a$ & $0.7 \pm 0.15 a$ & $1.0 \pm 0.00 \mathrm{a}$ & $0.8 \pm 0.13 a$ & $0.83 \pm 0.06 a$ \\
\hline 6 & $1.0 \pm 0.00 \mathrm{a}$ & $1.0 \pm 0.00 \mathrm{a}$ & $0.9 \pm 0.10 \mathrm{a}$ & $0.6 \pm 0.16 b$ & $0.88 \pm 0.09 a$ \\
\hline 7 & $0.9 \pm 0.10 a$ & $0.9 \pm 0.10 a$ & $1.0 \pm 0.00 \mathrm{a}$ & $0.3 \pm 0.15 b$ & $0.78 \pm 0.16 a$ \\
\hline 8 & $0.8 \pm 0.13 a$ & $0.8 \pm 0.13 a$ & $0.9 \pm 0.10 a$ & $0.1 \pm 0.10 b$ & $0.65 \pm 0.18 a$ \\
\hline 9 & $0.8 \pm 0.13 a$ & $1.0 \pm 0.00 \mathrm{a}$ & $0.9 \pm 0.10 \mathrm{a}$ & $0.6 \pm 0.16 b$ & $0.83 \pm 0.09 a$ \\
\hline 10 & $0.8 \pm 0.13 a$ & $0.8 \pm 0.13 a$ & $0.8 \pm 0.13 a$ & $0.7 \pm 0.15 a$ & $0.78 \pm 0.02 \mathrm{a}$ \\
\hline 11 & $0.6 \pm 0.16 a$ & $0.6 \pm 0.16 b$ & $0.5 \pm 0.17 \mathrm{a}$ & $0.6 \pm 0.16 b$ & $0.58 \pm 0.03 a$ \\
\hline 12 & $0.6 \pm 0.16 a$ & $0.8 \pm 0.13 a$ & $0.6 \pm 0.16 a$ & $0.7 \pm 0.15 a$ & $0.68 \pm 0.05 a$ \\
\hline 13 & $0.6 \pm 0.16 a$ & $0.5 \pm 0.17 b$ & $0.6 \pm 0.16 a$ & $0.5 \pm 0.17 b$ & $0.55 \pm 0.03 a$ \\
\hline 14 & $0.8 \pm 0.13 a$ & $0.9 \pm 0.10 a$ & $0.7 \pm 0.15 a$ & $0.7 \pm 0.15 a$ & $0.78 \pm 0.05 a$ \\
\hline 15 & $0.8 \pm 0.13 a$ & $0.9 \pm 0.10 a$ & $0.9 \pm 0.10 a$ & $1.0 \pm 0.00 \mathrm{a}$ & $0.90 \pm 0.04 a$ \\
\hline 16 & $0.7 \pm 0.15 a$ & $0.7 \pm 0.15 a$ & $0.8 \pm 0.13 a$ & $0.9 \pm 0.10 a$ & $0.78 \pm 0.05 a$ \\
\hline 17 & $0.8 \pm 0.13 a$ & $0.8 \pm 0.13 a$ & $0.8 \pm 0.13 a$ & $0.5 \pm 0.17 b$ & $0.73 \pm 0.07 a$ \\
\hline 18 & $0.9 \pm 0.10 a$ & $0.9 \pm 0.10 a$ & $0.8 \pm 0.13 a$ & $0.8 \pm 0.13 a$ & $0.85 \pm 0.03 a$ \\
\hline 19 & $0.8 \pm 0.13 a$ & $0.8 \pm 0.13 a$ & $0.5 \pm 0.17 \mathrm{a}$ & $0.5 \pm 0.17 b$ & $0.65 \pm 0.09 a$ \\
\hline 20 & $0.9 \pm 0.10 \mathrm{a}$ & $1.0 \pm 0.00 \mathrm{a}$ & $1.0 \pm 0.00 \mathrm{a}$ & $0.8 \pm 0.13 a$ & $0.93 \pm 0.05 a$ \\
\hline 21 & $1.0 \pm 0.00 \mathrm{a}$ & $0.9 \pm 0.10 a$ & $0.9 \pm 0.10 a$ & $0.5 \pm 0.17 b$ & $0.83 \pm 0.11 a$ \\
\hline 22 & $1.0 \pm 0.00 \mathrm{a}$ & $0.8 \pm 0.13 a$ & $0.9 \pm 0.10 a$ & $0.6 \pm 0.16 b$ & $0.83 \pm 0.09 a$ \\
\hline 23 & $0.9 \pm 0.10 \mathrm{a}$ & $0.8 \pm 0.13 a$ & $1.0 \pm 0.00 \mathrm{a}$ & $0.7 \pm 0.15 a$ & $0.85 \pm 0.06 a$ \\
\hline 24 & $1.0 \pm 0.00 \mathrm{a}$ & $1.0 \pm 0.00 \mathrm{a}$ & $0.9 \pm 0.10 \mathrm{a}$ & $0.5 \pm 0.17 b$ & $0.85 \pm 0.12 a$ \\
\hline 25 & $1.0 \pm 0.00 \mathrm{a}$ & $1.0 \pm 0.00 \mathrm{a}$ & $0.8 \pm 0.13 a$ & $0.4 \pm 0.16 b$ & $0.80 \pm 0.14 a$ \\
\hline 26 & $0.9 \pm 0.00 \mathrm{a}$ & $0.9 \pm 0.10 a$ & $0.9 \pm 0.10 a$ & $0.9 \pm 0.10 \mathrm{a}$ & $0.90 \pm 0.00 \mathrm{a}$ \\
\hline F (Treat) & 3.07 ** & 2.91 ** & $2.84^{\star \star}$ & $1.96^{* *}$ & $2.58^{* *}$ \\
\hline C. V. (\%) & 17.62 & 17.45 & 16.57 & 22.67 & 24.78 \\
\hline
\end{tabular}

'Means followed by the same letter are not statistically different from each other, by Scott-Knott test at 5\% probability; SE: average standard error; ${ }^{* *}$ significant at $1 \%$ probability; C. V.: coefficient of variation.

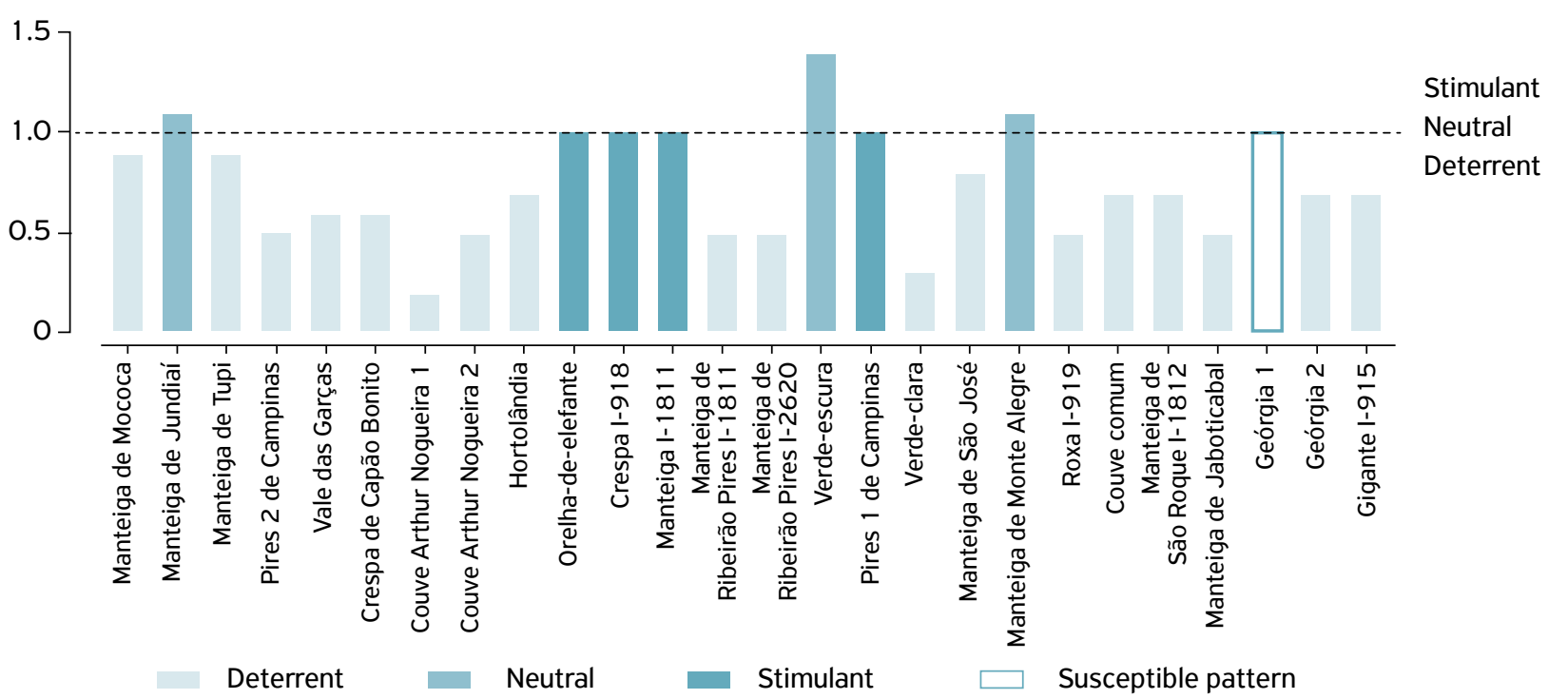

Figure 2. Attractiveness index of Ascia monuste orseis (Lepidoptera: Pieridae) in collard greens genotypes in non-choice test (temperature $25 \pm 2^{\circ} \mathrm{C}$, relative humidity $70 \pm 10 \%$ and photoperiod $12: 12$ light/darkness). 
In free-choice test, the genotypes 2, 11, 16, 12, 13 and 19 were classified as stimulants. The other genotypes were classified as deterrentes to $A$. monuste orseis (Fig. 3). In non-choice test, the genotypes 7, 9, 1 and 4 were classified as stimulants. Genotype 8 was taken as neutral and the others as deterrente to A. monuste orseis (Fig. 4).

The genotypes were significantly different in non-preference for oviposition by $A$. monuste orseis in free-choice $(\mathrm{F}=10.61 ; \mathrm{df}$ $=25 ; \mathrm{p}<0.0005)$ (Table 3). The genotypes 9 and 22 had the greatest number of egg mass of $A$. monuste orseis, and 12, 13,
10 and 16 less rates - the others showed intermediate values and 2, 6 and 7 were not oviposited. The genotypes 9 and 22 showed the highest values for number of eggs $(\mathrm{F}=12: 21 ; \mathrm{df}=$ 25; $\mathrm{p}<0.0005$ ) and $21,11,12,13,16,1,20,3,10,25,17$, 23 and 5 showed smallest numbers of eggs of $A$. monuste orseis.

The preference index for oviposition in non-choice test showed difference between the susceptible pattern (Geórgia I) (Fig. 5). Genotypes 9, 22, 15, 19, and 26 were classified as stimulants in relation to oviposition of $A$. monuste orseis, and the other genotypes were classified as deterrents.

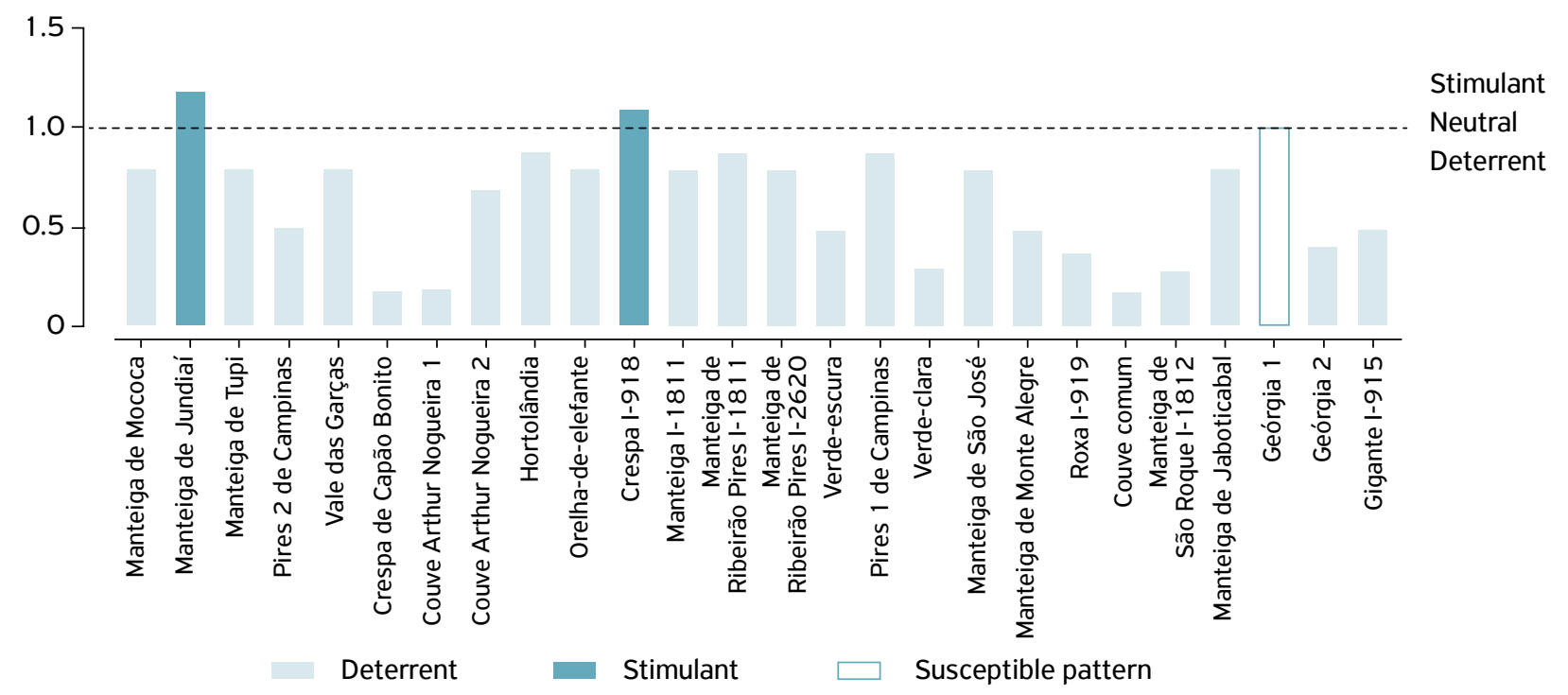

Figure 3. Feeding preference index of Ascia monuste orseis (Lepidoptera: Pieridae) in collard greens genotypes in free-choice test (temperature $25 \pm 2{ }^{\circ} \mathrm{C}$, relative humidity $70 \pm 10 \%$ and photoperiod $12: 12$ light/darkness).

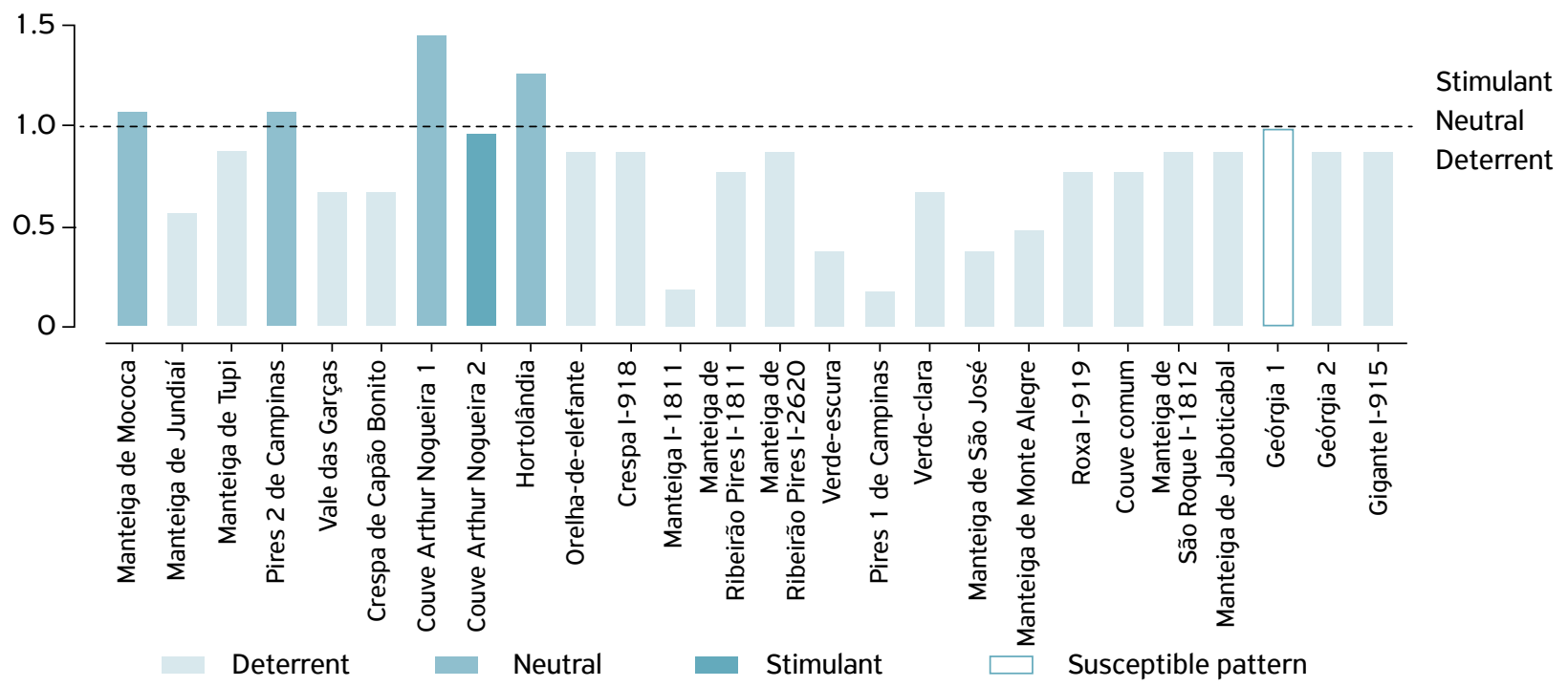

Figure 4. Feeding preference index of Ascia monuste orseis (Lepidoptera: Pieridae) in collard greens genotypes in non-choice test (temperature $25 \pm 2{ }^{\circ} \mathrm{C}$, relative humidity $70 \pm 10 \%$ and photoperiod $12: 12$ light/darkness). 


\section{DISCUSSION}

The attractiveness of $A$. monuste orseis in free and non-choice tests in collard greens revealed different responses in the genotypes. In attractiveness index in free-choice test, the total of eight genotypes was classified as neutral and 17 as deterrent. In attractiveness index in non-choice test, four genotypes were classified as neutral, 18 as deterrents and three as stimulants. The difference in attractiveness in free and non-choice tests is common in host plant resistance. Studies in which the strength characteristics were observed in free-choice test, but when performing in non-choice test those characteristics were not noticed (SCHLICK-SOUZA et al., 2011).

Comparing genotypes according to the attractiveness index in free and non-choice test, it was observed that the genotypes 1, 7, 8, 13, 3 and 25 were deterrents to A. monuste orseis in both tests. This less preference in these genotypes may be due to chemical metabolites emitted by plants, which interfere in the attraction of $A$. monuste orseis in these hosts (SHARON et al., 2009; BALDIN; BENEDUZZI, 2010; BALDIN et al., 2015).

The most attractive genotypes 20, 15 and 26 (non-choice test) were not the genotypes that showed the highest consumption by $A$. monuste orseis. It shows the different types of stimuli and response in the insect host selection (PANDA et al., 1979; LARA, 1991).

The genotypes 19, 15, 18, 12 and 16 were the least consumed in non-choice test, indicating feeding non-preference by $A$. monuste orseis. The low consumption in 16 genotype confirms the results by SCHLICK-SOUZA et al. (2011).

Table 3. Dry weight consumed (mg) of third-instar larvae and oviposition ( \pm SE) of Ascia monuste orseis in free- and non-choice tests in collard green genotypes (temperature $25 \pm 2{ }^{\circ} \mathrm{C}$, relative humidity $70 \pm 10 \%$ and photoperiod $12: 12$ light/darkness).

\begin{tabular}{|c|c|c|c|c|}
\hline \multirow{2}{*}{ Genotypes } & \multicolumn{2}{|c|}{ Non-preference for feeding } & \multicolumn{2}{|c|}{ Non-preference for oviposition } \\
\hline & Free-choice & Non-choice & Egg mass & Egg \\
\hline 1 & $13.09 \pm 2.20 \mathrm{a}$ & $22.57 \pm 1.50 c$ & $2.2 \pm 0.37 c$ & $21.0 \pm 4.11 \mathrm{~d}$ \\
\hline 2 & $28.42 \pm 4.75 a$ & $8.07 \pm 2.37 \mathrm{f}$ & $0.0 \pm 0.00 \mathrm{~d}$ & $0.0 \pm 0.00 \mathrm{~d}$ \\
\hline 3 & $13.79 \pm 2.85 a$ & $14.83 \pm 2.44 \mathrm{e}$ & $2.4 \pm 0.51 c$ & $18.4 \pm 4.24 \mathrm{~d}$ \\
\hline 4 & $6.32 \pm 3.07 b$ & $22.28 \pm 2.20 c$ & $3.8 \pm 0.73 b$ & $47.6 \pm 11.50 \mathrm{c}$ \\
\hline 5 & $13.08 \pm 4.86 a$ & $9.95 \pm 1.16 f$ & $3.2 \pm 0.37 b$ & $31.2 \pm 8.62 \mathrm{~d}$ \\
\hline 6 & $1.63 \pm 0.81 \mathrm{~b}$ & $9.66 \pm 0.04 f$ & $0.0 \pm 0.00 \mathrm{~d}$ & $0.0 \pm 0.00 \mathrm{~d}$ \\
\hline 7 & $2.04 \pm 1.05 b$ & $51.13 \pm 2.67 \mathrm{~g}$ & $0.0 \pm 0.00 \mathrm{~d}$ & $0.0 \pm 0.00 \mathrm{~d}$ \\
\hline 8 & $10.35 \pm 3.05 a$ & $18.32 \pm 2.04 d$ & $3.2 \pm 0.37 b$ & $44.0 \pm 7.50 \mathrm{c}$ \\
\hline 9 & $15.17 \pm 5.57 a$ & $28.61 \pm 2.10 b$ & $5.6 \pm 0.51 a$ & $136.4 \pm 1.91 \mathrm{a}$ \\
\hline 10 & $13.95 \pm 4.59 a$ & $14.49 \pm 0.00 \mathrm{e}$ & $1.2 \pm 0.37 d$ & $26.4 \pm 10.06 \mathrm{~d}$ \\
\hline 11 & $24.39 \pm 3.87 \mathrm{a}$ & $13.00 \pm 0.00 \mathrm{e}$ & $1.6 \pm 0.51 c$ & $14.6 \pm 5.11 \mathrm{~d}$ \\
\hline 12 & $13.01 \pm 2.48 a$ & $2.20 \pm 2.57 \mathrm{a}$ & $0.8 \pm 0.37 d$ & $15.0 \pm 6.42 \mathrm{~d}$ \\
\hline 13 & $17.28 \pm 3.37 \mathrm{a}$ & $12.57 \pm 2.28 \mathrm{e}$ & $1.0 \pm 0.63 d$ & $15.4 \pm 10.63 d$ \\
\hline 14 & $14.18 \pm 4.05 a$ & $13.98 \pm 0.99 \mathrm{e}$ & $1.4 \pm 0.51 c$ & $25.2 \pm 8.85 \mathrm{~d}$ \\
\hline 15 & $7.14 \pm 1.83 b$ & $4.29 \pm 0.49 a$ & $2.4 \pm 0.51 c$ & $84.0 \pm 24.84 b$ \\
\hline 16 & $14.67 \pm 3.50 \mathrm{a}$ & $2.18 \pm 0.00 \mathrm{a}$ & $1.2 \pm 0.37 \mathrm{~d}$ & $17.4 \pm 5.68 d$ \\
\hline 17 & $3.19 \pm 1.44 b$ & $9.60 \pm 0.00 \mathrm{f}$ & $1.6 \pm 0.51 c$ & $29.0 \pm 10.09 d$ \\
\hline 18 & $6.75 \pm 2.05 b$ & $4.20 \pm 0.00 \mathrm{a}$ & $4.0 \pm 0.71 b$ & $41.2 \pm 11.28 c$ \\
\hline 19 & $14.21 \pm 4.17 \mathrm{a}$ & $6.20 \pm 0.00 \mathrm{a}$ & $2.8 \pm 0.37 c$ & $56.2 \pm 12.36 c$ \\
\hline 20 & $4.72 \pm 2.01 b$ & $12.30 \pm 1.61 \mathrm{e}$ & $2.2 \pm 0.58 c$ & $24.2 \pm 12.29 \mathrm{~d}$ \\
\hline 21 & $2.36 \pm 0.24 b$ & $12.27 \pm 1.42 \mathrm{e}$ & $1.6 \pm 0.24 c$ & $7.4 \pm 1.86 \mathrm{~d}$ \\
\hline 22 & $3.50 \pm 1.51 b$ & $13.21 \pm 2.28 \mathrm{e}$ & $6.4 \pm 0.51 a$ & $131.8 \pm 5.06 a$ \\
\hline 23 & $13.66 \pm 4.72 \mathrm{a}$ & $14.38 \pm 1.33 \mathrm{e}$ & $2.0 \pm 0.32 c$ & $30.8 \pm 10.95 d$ \\
\hline 24 & $19.26 \pm 2.72 \mathrm{a}$ & $17.11 \pm 1.72 \mathrm{e}$ & $3.6 \pm 0.93 b$ & $49.0 \pm 20.55 c$ \\
\hline 25 & $5.57 \pm 1.56 b$ & $14.39 \pm 1.90 \mathrm{e}$ & $2.2 \pm 0.58 c$ & $28.6 \pm 5.02 d$ \\
\hline 26 & $6.68 \pm 1.61 b$ & $12.81 \pm 2.03 \mathrm{e}$ & $2.0 \pm 0.32 c$ & $57.2 \pm 5.75 c$ \\
\hline F (Treat) & $5.12^{* *}$ & $33.13^{* *}$ & $10.61^{* *}$ & 12.21 ** \\
\hline C. V. (\%) & 41.28 & 20.24 & 21.32 & 33.16 \\
\hline
\end{tabular}

'Means followed by the same letter are not statistically different from each other, by Scott-Knott test at $5 \%$ probability; SE: average standard error; **significant at $1 \%$ probability; C. V.: coefficient of variation. 


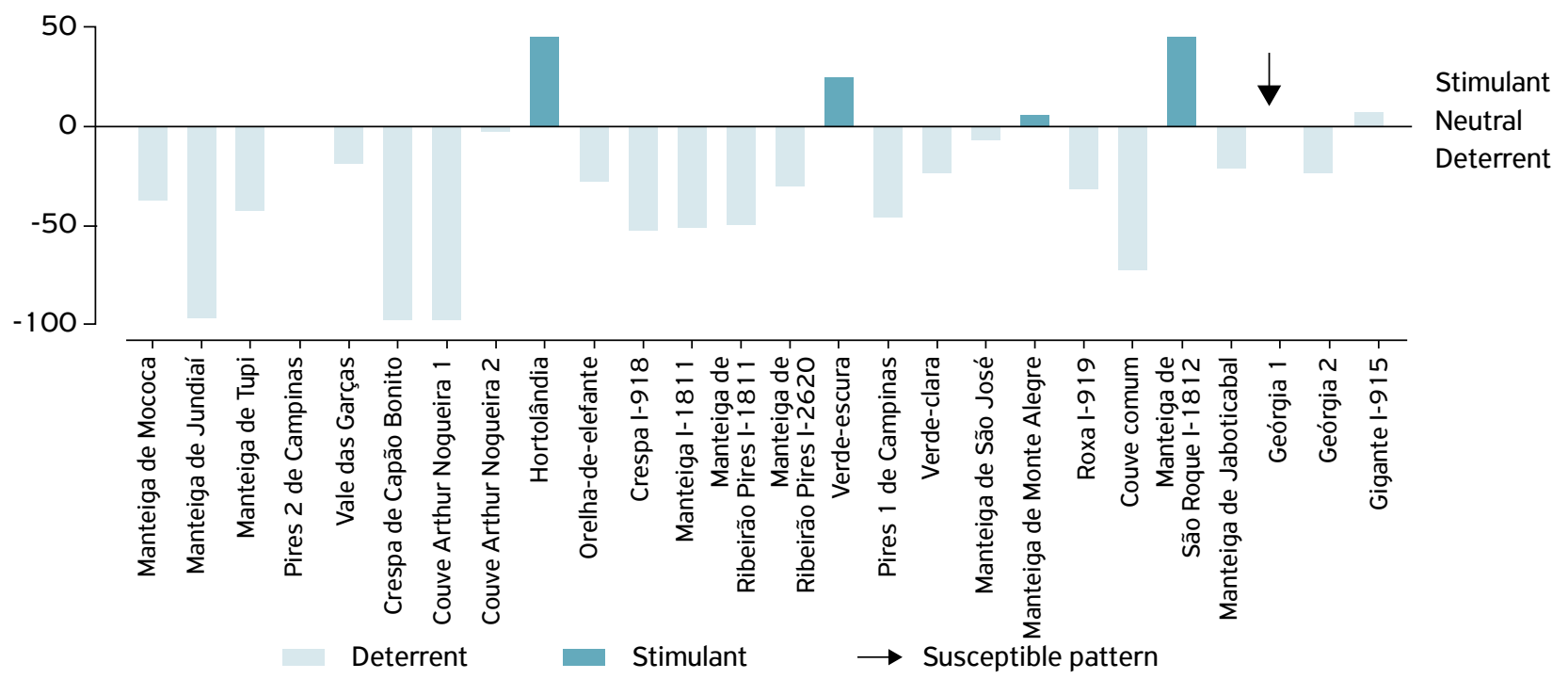

Figure 5. Oviposition preference index of adults of Ascia monuste orseis (Lepidoptera: Pieridae) in collard greens genotypes in freechoice test (temperature $25 \pm 2^{\circ} \mathrm{C}$, relative humidity $70 \pm 10 \%$ and photoperiod $12: 12$ light/darkness).

The resistance in this genotype may be related to morphological characteristics in the leaf as the presence of waxiness on the leaf surface (FARNHAM; ELSEY, 1995), chemical as the presence of glucosinolate (BERNAYS; CHAPMAN, 1994; COLE, 1997), or physical characteristics such as the surface color (VENDRAMIM; GUZZO, 2009; SCHLICKSOUZA et al., 2011).

In preference for oviposition in non-choice test, the genotypes 2, 6 and 7 were not oviposited by $A$. monuste orseis, indicating antixenosis (non-preference for oviposition), while the genotypes 9 and 22 presented as susceptible and were the most oviposited. Low preference in oviposition by $A$. monuste orseis in two genotypes was also observed by SCHLICKSOUZA et al. (2011). These authors observed that the collard greens with bright green color of leaves were less oviposited by A. monuste orseis, which can be observed in this study, except on six genotypes. CATTA-PRETA; ZUCOLOTO (2003) and VENDRAMIM; GUZZO (2009) describe the same process by the host insect screening, but there are also volatile chemicals emitted by the plant in the host selection.

The attractiveness index for oviposition and feeding found genotypes classified as deterrents to $A$. monuste orseis compared to susceptible pattern (Geórgia I). It is possible that these deterrents genotypes have chemicals metabolites such as glucosinolates (FARNHAM; ELSEY, 1995; COLE, 1997), morphological characteristics such as high wax content in leaves (RENWICK et al., 1989), physical and leaf coloring (VENDRAMIM; GUZZO, 2009), or a combination of these characteristics, which isn't favorable to the pest in the host selection, reducing the feeding and oviposition attractiveness.

The results indicate that genotypes $2,6,7,10,12,13$, and 16 are resistant to $A$. monuste orseis, showing antixenosis (non-preference for oviposition); and 12, 15, 16, 18, and 19 presented non-preference for feeding. These results are important for breeding programs to collard greens, aiming at incorporating resistance to $A$. monuste orseis.

\section{ACKNOWLEDGMENTS}

The authors thank the National Council of Research and Technology of Brazil (CNPq) for grant support to F.G.J. (Process 311280/2015-3). We also thank the Goiano Federal Institute, Campus Urutaí, for support.
BALDIN, E.L.L.; BENEDUZZI, R.A. Characterization of antibiosis and antixenosis to the whitefly silverleaf Bemisia tabaciB biotype (Hemiptera: Aleyrodidae) in several squash varieties. Journal of Pest Science, v.83, n.3, p.221-227, 2010. http://dx.doi. org/10.1007/s10340-010-0289-2
BALDIN, E.L.L.; SCHLICK-SOUZA, E.C.; LOURENÇÃO, A.L.; CAMARGO, R.S. Resistance of collard greens to Ascia monuste orseis (Lepidoptera: Pieridae). Arthropod-Plant Interaction, v.9, n.1, p.67-74, 2015 . doi: $10.1007 /$ s1 1829-014-9344-x 
BERNAYS, E.A.; CHAPMAN, R.F. Host-plant selection by phytophagous insects. New York: Chapman and Hall, 1994. 312p.

CATTA-PRETA, P.D.; ZUCOLOTO, F.S. Oviposition behavior and performance aspects of Ascia monuste (Godart, 1919) (Lepidoptera: Pieridae) on kale (Brassica oleracea var. acephala). Revista Brasileira de Entomologia, v.47, n.2, p.169-174, 2003. http://dx.doi.org/10.1590/S0085-56262003000200003

CHAMBERLIN, J.R.; KOK, L.T. Cabbage lepidopterous pests and their parasites in Southwestern Virginia. Journal of Economic Entomology, v.79,n.2,p.629-632, 1986.https://doi.org/10.1093/jee/79.3.629

COLE, R.A. The relative importance of glucosinolates and amino acids to the development of two aphid pests Brevicoryne brassicae and Myzus persicae on wild and cultivated brassica species. Entomologia Experimentalis et Applicata, v.85, n.2, p.121-133, 1997. https://doi.org/10.1046/j.1570-7458.1997.00242.x

EIGENBRODE, S.D.; TRUMBLE, J.T. Host plant resistance to insects in integrated pest management in vegetable crops. Journal Agricultural Entomology, v.1 1, n.4, p.201-224, 1994.

FARNHAM, M.W.; ELSEY, K.D. Recognition of Brassica oleracea L. resistance against the silverleaf whitefly. HortScience, v.30, n.2, p.343-347, 1995.

FENEMORE, P.G. Oviposition of potato tuber moth, Phthorimaea operculella Zell. (Lepidoptera: Gelechiidae); identification of host-plant factors influencing oviposition response. New Zealand Journal of Zoology, v.7, n.3, p.435-439, 1980.

FILGUEIRA, F.A.R. Novo manual de olericultura: agrotecnologia moderna na produção e comercialização de hortaliças. 2. ed. rev. ampl. Viçosa: UFV, 2008. 421p.

GALLO, D.; NAKANO, O.; SILVEIRA NETO, S.; CARVALHO, R.P.L.; BATISTA, G.C.; BERTI FILHO, E.; PARRA, J.R.P.; ZUCCHI, R.A.; ALVES, S.B.; VENDRAMIM, J.D.; MARCHINI, L.C.; LOPES, J.R.S.; OMOTO, C. Entomologia agrícola. Piracicaba: FEALQ, 2002. 920p.

KOK, L.T.; ACOSTA-MARTINEZ, J.A. Differential susceptibility of Cotesia orobenae, a parasitoid of the cross-striped cabbageworm, to commonly used insecticides in Cruciferae. Biocontrol, v.46, n.4, p.419-426, 2001

LARA, F.M. Princípios de resistência de plantas a insetos. São Paulo: Ícone, 1991.336p.

LASOTA, J.A.; KOK, L.T. Seasonal abundance of imported cabbageworm (Lepidoptera: Pieridae), cabbage looper (Lepidoptera: Noctuidae), and the diamondback moth (Lepidoptera: Plutellidae) on cabbage in Southwestern Virginia. Journal of Economic Entomology, v.82, n.3, p.81 1-818, 1989. https:// doi.org/10.1093/jee/82.3.811
NOGUEIRA, L.; PAIVA, L.A.; ALMEIDA, A.C.S.; RIBEIRO, Z.A.; BOIÇA JUNIOR, A.L.; JESUS, F.G. Antibiosis in Ascia monuste orseis Godart (Lepidoptera: Pieridae) caused by kale genotypes. African Journal of Biotechnology, v.14, n.41, p.2876-2882, 2015. doi: 10.5897/AJB2015.14530

PANDA, N. Principles of host-plant resistance to insect pest. New York: Alanheld, Osmun \& Co and Universal Books, 1979. 86p.

PRATISSOLI, D.; POLANCZYK, R.A.; DALVI, L.P.; COCHETO, J.G.; MELO, D.F. Ocorrência de Ascia monuste orseis (Lepidoptera: Pieridae) danificando mudas de Crataeva tapia. Ciência Rural, v.37, n.3, p.874-875, 2007. http://dx.doi.org/10.1590/ S0103-84782007000300042

RENWICK, J.A.A.; RADKE, C.D.; SACHDEV-GUPTA, K. Chemical constituents of Erysimum cheiranthoides deterring oviposition by the cabbage butterfly, Pieris rapae. Journal of Chemical Ecology, v.15, n.8, p.2161-2168, 1989.

ROEL, A.R.; VENDRAMIM, J.D.; FRIGHETTO, R.T.S.; FRIGHETTO, N. Efeito do extrato acetato de etila de Trichilia pallida Swartz (Meliaceae) no desenvolvimento e sobrevivência da lagarta-docartucho. Bragantia, v.59, n.1, p.53-58, 2000. http://dx.doi. org/10.1590/S0006-87052000000100009

SCHLICK-SOUZA, E.C.; BALDIN, E.L.L.; LOURENÇÃO, A.L. Variation in the host preferences and responses of Ascia monuste orseis Godart (Lepidoptera: Pieridae) to cultivars of collard greens Brassica oleracea (L.) var. acephala. Journal of Pest Science, v.84, p.429436, 2011 . https://doi.org/10.1007/s 10340-011-0378-x

SEIFI, A.; VISSER, R.G.F.; YULING, B. How to effectively deploy plant resistance to pests and pathogens in crop breeding. Euphytica, v.190, n.3, p.321-334, 2013.

SHARON, R.; ZAHAVI, T.; SOROKER, V.; HARARI, A.R. The effect of grape vine cultivars on Lobesia botrana (Lepidoptera: Tortricidae) population levels. Journal of Pest Science, v.82, n.2, p.187193, 2009.

SMITH, C.M. Plant resistance to arthropods: molecular and conventional approaches. Berlin: Springer, 2005. 423p.

THULER, R.T.; DE BORTOLI, A.S.; HOFFMANN-CAMPO, C.B. Classificação de cultivares de brássicas com relação à resistência à traça-das-crucíferas e à presença de glucosinolatos. Pesquisa Agropecuária Brasileira, v.42, n.4, p.467-474, 2007. http:// dx.doi.org/10.1590/S0100-204X2007000400003

VENDRAMIM, J.D.; GUZZO, E.C. Resistência de plantas e a bioecologia e nutrição dos insetos. In: PANIZZI, A.R.; PARRA, J.R.P. (Eds). Bioecologia e nutrição de insetos: base para o manejo integrado de pragas. Brasília: Embrapa Informação Tecnológica; Londrina: Embrapa Soja, 2009. p.1055-1105. 